\title{
Angioedema. Interdisciplinary diagnostic and therapeutic recommendations of the Polish Dermatological Society (PTD) and Polish Society of Allergology (PTA)
}

\author{
Obrzęk naczynioruchowy. Interdyscyplinarne rekomendacje diagnostyczno- \\ -terapeutyczne Polskiego Towarzystwa Dermatologicznego (PTD) \\ i Polskiego Towarzystwa Alergologicznego (PTA)
}

Roman J. Nowicki', Elżbieta Grubska-Suchanek', Grzegorz Porębski², Marek L. Kowalski ${ }^{3}$ Karina Jahnz-Różyk4,

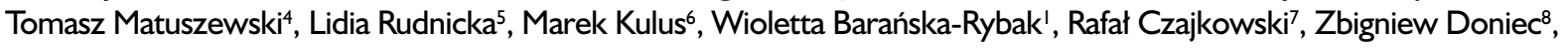
Cezary Kowalewski', Beata Kręcisz' ${ }^{10}$, Magdalena Lange', Joanna Narbutt' ', Małgorzata Olszewska ${ }^{5}$,

Małgorzata Sokołowska-Wojdyło', Aneta Szczerkowska-Dobosz', Radosław Śpiewak'2, Magdalena Trzeciak', Aleksandra Wilkowska'

\author{
'Department of Dermatology, Venerology and Allergology, Medical University of Gdansk, Poland \\ 2Department of Clinical and Environmental Allergology, Jagiellonian University, Clinical and Environmental Allergology Centre, \\ University Hospital in Krakow, Poland \\ ${ }^{3}$ Department of Immunology and Allergy, Medical University of Lodz, Poland \\ ${ }^{4}$ Department of Internal Medicine, Allergology and Clinical Immunology, Military Institute of Medicine, Warsaw, Poland \\ 5Department of Dermatology, Medical University of Warsaw, Poland \\ ${ }^{6}$ Department of Pediatric Pneumonology and Allergology, Medical University of Warsaw, Poland \\ 'Department of Dermatology and Venereology, Ludwik Rydygier Collegium Medicum in Bydgoszcz, Nicolaus Copernicus \\ University in Torun, Poland \\ ${ }^{8}$ Department of Pneumonology, Jan and Irena Rudnik Division of the Institute of Tuberculosis and Pulmonary Diseases in Rabka, Poland \\ 'Department of Dermatology and Immunodermatology, Medical University of Warsaw, Poland \\ ${ }^{10}$ Dermatology Clinic, Medical and Health Science Faculty, Jan Kochanowski University, Kielce, Poland \\ "Department of Dermatology, Pediatric and Oncological Dermatology, Medical University of Lodz, Poland \\ ${ }^{12}$ Department of Experimental Dermatology and Cosmetology, Jagiellonian University Collegium Medicum, Krakow, Poland \\ 'Katedra i Klinika Dermatologii, Wenerologii i Alergologii, Gdański Uniwersytet Medyczny, Polska \\ 2Zakład Alergologii Klinicznej i Środowiskowej, Uniwersytet Jagielloński, Centrum Alergologii Klinicznej i Środowiskowej Szpitala \\ Uniwersyteckiego w Krakowie, Polska \\ ${ }^{3}$ Klinika Immunologii i Alergii, Uniwersytet Medyczny w Łodzi, Polska \\ ${ }^{4}$ Klinika Chorób Wewnętrznych, Pneumonologii, Alergologii i Immunologii Klinicznej, Wojskowy Instytut Medyczny, Warszawa, Polska \\ ${ }^{5}$ Katedra i Klinika Dermatologiczna, Warszawski Uniwersytet Medyczny, Polska \\ ${ }^{6}$ Klinika Pneumonologii i Alergologii Wieku Dziecięcego, Warszawski Uniwersytet Medyczny, Polska \\ ${ }^{7}$ Katedra Dermatologii i Wenerologii, Collegium Medicum im. Ludwika Rydygiera w Bydgoszczy, Uniwersytet Mikołaja Kopernika \\ w Toruniu, Polska \\ ${ }^{8}$ Klinika Pneumonologii, Instytut Gruźlicy i Chorób Płuc, Oddział Terenowy im. Jana i Ireny Rudników w Rabce, Polska \\ ${ }^{9}$ Klinika Dermatologii i Immunodermatologii, Warszawski Uniwersytet Medyczny, Polska \\ ${ }^{10}$ Klinika Dermatologii, Wydział Lekarski i Nauk o Zdrowiu, Uniwersytet Jana Kochanowskiego w Kielcach, Polska \\ "Klinika Dermatologii, Dermatologii Dziecięcej i Onkologicznej, Uniwersytet Medyczny w Łodzi, Polska \\ ${ }^{12 Z a k ł a d ~ D e r m a t o l o g i i ~ D o s ́ w i a d c z a l n e j ~ i ~ K o s m e t o l o g i i, ~ U n i w e r s y t e t ~ J a g i e l l o n ́ s k i ~ C o l l e g i u m ~ M e d i c u m, ~ K r a k o ́ w, ~ P o l s k a ~}$
}

\begin{abstract}
Angioedema is a non-inflammatory edema of the subcutaneous tissue and/or mucosal membranes. It commonly coexists with urticaria and is considered a deep form of urticaria. Less commonly, it occurs as an isolated disease in one of two basic forms: acquired angioedema and hereditary angioedema. Four types of acquired angioedema and seven types of hereditary angioedema were difinied. The treatment of angio-
\end{abstract}




\section{CORRESPONDING AUTHOR/} ADRES DO KORESPONDENCJI:

prof. Roman J. Nowicki

Katedra i Kliniki Dermatologii,

Wenerologii i Alergologii

Gdański Uniwersytet Medyczny

Centrum Medycyny

Nieinwazyjnej

ul. Smoluchowskiego 17

80-214 Gdańsk

tel. +48585844010

e-mail: rnowicki@gumed.edu.pl edema depends on its form and etiological factors, with hereditary angioedema posing a most significant challenge.

\section{STRESZCZENIE}

Obrzęk naczynioruchowy jest niezapalnym obrzękiem tkanki podskórnej i/lub błon śluzowych. Najczęściej współistnieje z bąblami pokrzywkowymi i traktowany jest jako głęboka odmiana pokrzywki. Rzadziej ma charakter izolowany i występuje w dwóch podstawowych odmianach: nabytej i wrodzonej. Wyróżnia się 4 typy nabytego obrzęku naczynioruchowego oraz 7 typów wrodzonego obrzęku naczynioruchowego. Leczenie zależy od postaci obrzęku naczynioruchowego i czynników przyczynowych. Uwarunkowana genetycznie postać wrodzona stanowi szczególnie duże wyzwanie dla lekarzy wielu specjalności, zwłaszcza dermatologów i alergologów.

Key words: angioedema, icatibant, ecallantide, rituximab, Berinert, Ruconest, Firazyr, Landelumab.

Słowa kluczowe: obrzęk naczynioruchowy, ikatybant, ekalantyd, rytuksymab, Berinert, Ruconest, Firazyr, Landelumab.
Angioedema (AE), first described in 1882 by a German physician Heinrich Quincke (Quincke edema), is a non-inflammatory, self-limiting type of edema of the subcutaneous tissue and/or mucosal membranes. AE symptoms result from increased permeability of blood vessels caused by vasoactive mediators [1-4]. Edema may coexist with urticaria or occur in isolation (without accompanying wheals) [5].

The most common manifestation of isolated AE is limited, asymmetrical skin and subcutaneous tissue swelling. The skin over the edema is not inflamed or itchy. The edema usually persists for 48 to 72 hours, can be limited to one site or occur at multiple sites simultaneously. It usually affects the skin of the face, mainly lips and eyelids, but can also affect the torso, limbs and genital areas. The edema can also affect respiratory mucosa; in this form, acute pharyngolaryngeal edema may be life-threatening. A less common and often misdiagnosed AE manifestation are gastrointestinal lesions accompanied by pain, nausea, vomiting and diarrhea. Severe edema at this location can imitate symptoms of acute abdomen. Particularly atypical forms of AE can be associated with symptoms related to the urinary system, motor system and central nervous system $[2,5-10]$.

Isolated angioedema can assume two basic forms: 1) acquired angioedema (AAE) and

2) hereditary angioedema (HAE).

Currently, a total of 4 types of AAE and 7 types of HAE have been identified (table 1) [6, 10-23].
Obrzęk naczynioruchowy (angioedema - AE), opisany po raz pierwszy w 1882 roku przez niemieckiego lekarza Heinricha Quinckego (obrzęk Quinckego), jest niezapalnym, samoograniczającym się obrzękiem tkanki podskórnej i/lub błon śluzowych. Wystąpienie objawów AE wiąże się ze wzrostem przepuszczalności naczyń krwionośnych wywołanym przez wazoaktywne mediatory [1-4]. Obrzęk może wspólistnieć z pokrzywką lub mieć charakter izolowany (bez towarzyszących bąbli pokrzywkowych) [5].

Najczęstszą manifestacją izolowanego AE są ograniczone, niesymetryczne obrzęki skóry i tkanki podskórnej. Skóra pokrywająca zmiany obrzękowe jest niezmieniona zapalnie i nie swędzi. Obrzęki utrzymują się zwykle od 48 do 72 godzin, są pojedyncze lub pojawiają się w kilku miejscach. Najczęściej dotyczą skóry twarzy, głównie warg i powiek, mogą występować także na tułowiu, kończynach oraz w okolicy narządów płciowych. W niektórych przypadkach obrzęki obejmują również błony śluzowe dróg oddechowych - w tej postaci ostry obrzęk gardła i krtani może stanowić zagrożenie dla życia chorego. Rzadszą i często niewłaściwie rozpoznawaną manifestacją AE są zmiany w przewodzie pokarmowym, którym towarzyszą bóle, nudności, wymioty i biegunka. Nasilone obrzęki w tej lokalizacji mogą imitować objawy „ostrego brzucha”. W szczególnie nietypowych postaciach AE mogą się pojawić objawy ze strony układu moczowego, narządu ruchu oraz ośrodkowego układu nerwowego [2, 5-10]. 


\section{ACQUIRED ANGIOEDEMA (AAE)}

A number different factors may cause AAE; usually these are the same factors that trigger urticaria wheals. This type of edema can be caused by certain drugs as well as some diseases. In some cases, available diagnostic methods are insufficient to identify the cause - this is when idiopathic edema is diagnosed.

Types of AAE:

1) AAE-IH - idiopathic histaminergic AAE,

2) AAE-InH - idiopathic non-histaminergic AAE,

3) AAE-C1-INH - AAE with C1 inhibitor deficiency,

4) AAE-ACE-I - AAE related to ACE-I.

\section{Idiopathic histaminergic acquired angioedema (AAE-IH)}

This is one of the most common types of isolated AE. The mechanism of this type of edema involves IgE-mediated or non-IgE-mediated mast cell activation with histamine release, and therefore it is termed "histaminergic" edema. Similarly to urticaria, various factors may trigger this type of edema, e.g., drugs, foods, insect venoms and other environmental allergens, as well as physical factors. AAE-IH's relation to infectious foci and autoimmune diseases is unclear.
Izolowany obrzęk naczynioruchowy występuje w dwóch podstawowych odmianach:

1) nabytej (acquired angioedema - AAE) i

2) wrodzonej (hereditary angioedema - HAE).

Obecnie wyróżnia się 4 typy AAE oraz 7 typów HAE (tab. 1) [6, 10-23].

\section{NABYTY OBRZĘK NACZYNIORUCHOWY (AAE)}

Istnieje wiele różnych przyczyn AAE, w większości są to te same czynniki, które odpowiadają za powstawanie zmian pokrzywkowych. Obrzęk może być wywołany niektórymi lekami, jak również może stanowić manifestację różnych chorób. W części przypadków nie jesteśmy w stanie ustalić przyczyny zmian obrzękowych dostępnymi metodami diagnostycznymi - rozpoznajemy wówczas postać idiopatyczną obrzęku.

Odmiany AAE:

1) AAE-IH - zależny od histaminy (idiopathic histaminergic $A A E)$,

2) AAE-InH - niezależny od histaminy (idiopathic non-histaminergic $A A E)$,

3) AAE-C1-INH - związany z niedoborem C1-INH (AAE with $C 1$ inhibitor deficiency),

4) AAE-ACE-I - związany z leczeniem inhibitorami konwertazy angiotensyny ( $A A E$ related to $A C E-I)$.

Table I. Classification of isolated angioedema (without accompanying urticaria)

\begin{tabular}{|c|c|c|}
\hline \multirow[t]{4}{*}{ Acquired (AAE) } & \multirow[t]{2}{*}{ Idiopathic } & Histaminergic (AAE-IH) \\
\hline & & Non-histaminergic (AAE-InH) \\
\hline & \multirow[t]{2}{*}{ With known etiology } & With $\mathrm{Cl}$-INH deficiency (AAE- $\mathrm{Cl}$-INH) \\
\hline & & Induced by ACE-I (AAE-ACE-I) \\
\hline \multirow[t]{7}{*}{ Hereditary (HAE) } & \multirow{2}{*}{ With $\mathrm{Cl}$-INH deficiency (HAE-CI-INH) } & With reduced $\mathrm{Cl}-\mathrm{INH}$ levels, type I (HAE-I) \\
\hline & & With impaired $\mathrm{Cl}$-INH activity, type 2 (HAE-2) \\
\hline & \multirow[t]{5}{*}{ With normal Cl-INH (HAE-nCl-INH) } & With a mutation in factor XII (HAE-FXII) \\
\hline & & With a mutation in angiopoietin (HAE-ANG) \\
\hline & & With a mutation in plasminogen (HAE-PLG) \\
\hline & & With a mutation in kininogen I (HAE-KNGI) \\
\hline & & Of unknown etiology (HAE-UNK) \\
\hline
\end{tabular}

Tabela I. Klasyfikacja izolowanego (bez obecności pokrzywki) obrzęku naczynioruchowego

\begin{tabular}{|c|c|c|}
\hline \multirow[t]{4}{*}{ Nabyty (AAE) } & \multirow[t]{2}{*}{ Idiopatyczny } & Zależny od histaminy (AAE-IH) \\
\hline & & Niezależny od histaminy (AAE-InH) \\
\hline & \multirow[t]{2}{*}{ O znanym mechanizmie } & Z niedoboru $\mathrm{Cl}-\mathrm{INH}(\mathrm{AAE}-\mathrm{Cl}-\mathrm{INH})$ \\
\hline & & Indukowany ACE-I (AAE-ACE-I) \\
\hline \multirow[t]{7}{*}{ Wrodzony (HAE) } & \multirow[t]{2}{*}{ Z niedoborem $\mathrm{Cl}-\mathrm{INH}(\mathrm{HAE}-\mathrm{Cl}-\mathrm{INH})$} & Ze zmniejszonym stężeniem Cl -INH, typ I (HAE-I) \\
\hline & & Z obniżoną aktywnością $\mathrm{Cl}$-INH, typ 2 (HAE-2) \\
\hline & \multirow{5}{*}{$\begin{array}{l}\text { Z prawidłowym Cl-INH (HAE-nCl- } \\
-\mathrm{INH})\end{array}$} & Z mutacją genu czynnika XII (HAE-FXII) \\
\hline & & Z mutacją genu angiopoetyny (HAE-ANG) \\
\hline & & Z mutacją genu plazminogenu (HAE-PLG) \\
\hline & & Z mutacją genu kininogenu I (HAE-KNGI) \\
\hline & & O nieznanym podłożu (HAE-UNK) \\
\hline
\end{tabular}


When the factor that activated mast cells cannot be identified, idiopathic edema is diagnosed $[2,5]$. The condition can occur at any age. Most commonly it is acute, sometimes chronic and recurrent. The symptoms mainly affect the face, predominantly lips and eyelids, less commonly the larynx or the gastrointestinal mucosa. Family history of AE is negative [2].

Diagnostic workup: it is important to try to identify the etiological factors responsible and any comorbidities, and to rule out other types of AAE and $\operatorname{HAE}[2,18]$.

Treatment: AHs, sometimes at multiplied daily doses, similarly as in urticaria, and in acute forms additionally glucocorticosteroids (GCS) and adrenaline [2].

\section{Idiopathic non-histaminergic acquired angioedema (AAE-InH)}

Causes and clinical presentation of this form of edema are similar to AAE-InH, but the symptoms are not resolved with antihistamines, hence the name 'non-histaminergic' edema. The principal mediator responsible for the symptoms in AAE-InH is bradykinin, but the role of leukotrienes, prostaglandins and platelet activating factor cannot be ruled out [2]. This disease mainly affects middle-aged patients; women are affected slightly more often. Most patients exhibit facial edema; approximately one third also develop upper respiratory and gastrointestinal symptoms. This type of edema, as the AAE-IH, is not a familial disease $[2,20]$.

Diagnostic workup: same as recommended for AAE-IH.

Treatment: a large number of patients respond well to tranexamic acid - a synthetic amino acid with antihemorrhagic activity. In patients with contraindications to this drug, GCS, cyclosporine A or omalizumab may be considered. The varying responses of AAE-InH patients to different therapies indicate heterogeneity of this type of edema and participation of various mediators in its pathomechanism $[2,22,23]$.

\section{Acquired angioedema with $\mathrm{Cl}$ inhibitor deficiency (AAE-CI-INH)}

This form of the disorder is diagnosed in patients with $\mathrm{C} 1$ inhibitor deficiency without a mutation in the C1-INH gene (SERPING1) and without a family history of edema [2]. Reduced C1-INH levels in this type of $\mathrm{AE}$ may result from increased consumption of this inhibitor or from production of C1-INH-neutralizing antibodies. This is observed in lymphoproliferative diseases, gammopathies, as well as autoimmune disorders, e.g. systemic lupus erythematosus [2, 10, 24].

AAE-C1-INH occurs in adults of both sexes, usually over 40 years of age. The edema usually affects the

\section{Nabyty obrzęk naczynioruchowy zależny od histaminy (AAE-IH)}

Jest to jedna $z$ najczęstszych odmian izolowanego AE. Mechanizm tej postaci obrzęku wiąże się $\mathrm{z}$ aktywacją komórek tucznych zależną od IgE lub niezależną od IgE oraz z uwalnianiem histaminy, dlatego jest określany jako obrzęk „histaminergiczny”. Bodźcami wyzwalającymi tę odmianę obrzęku mogą być, podobnie jak $w$ pokrzywce, różne czynniki, takie jak leki, pokarmy, jady owadów i inne alergeny środowiskowe oraz czynniki fizykalne. Niejednoznaczny jest związek AAE-IH z ogniskami infekcji i chorobami autoimmunologicznymi. Gdy nie udaje się wykryć czynnika odpowiedzialnego za aktywację komórek tucznych, rozpoznaje się postać idiopatyczną obrzę$\mathrm{ku}[2,5]$. Choroba może się pojawić w każdym wieku. Obrzęk najczęściej występuje w postaci ostrej, niekiedy ma charakter przewlekły, nawracający. Objawy dotyczą głównie twarzy, przede wszystkim warg i powiek, rzadziej dochodzi do obrzęku krtani i zajęcia śluzówki przewodu pokarmowego. Wywiad rodzinny w kierunku AE jest ujemny [2].

Diagnostyka: istotna jest próba poszukiwania czynników odpowiedzialnych za wywoływanie objawów i chorób wspólistniejących oraz wykluczenie innych odmian AAE i HAE $[2,18]$.

Leczenie: leki przeciwhistaminowe, niekiedy w zwielokrotnionej dawce dobowej, podobnie jak w pokrzywce, a w postaciach ostrych dodatkowo glikokortykosteroidy (GKS) i adrenalina [2].

\section{Nabyty idiopatyczny obrzęk naczynioruchowy niezależny od histaminy (AAE-InH)}

Przyczyny i obraz kliniczny tej odmiany obrzęku są podobne jak w AAE-InH, ale objawy nie ustępują po zastosowaniu leków przeciwhistaminowych, stąd określenie obrzęk „niehistaminergiczny”. Mediatorem odpowiedzialnym za pojawienie się zmian obrzękowych w AAE-InH jest głównie bradykinina, nie można wykluczyć również roli leukotrienów, prostaglandyn lub czynnika aktywującego płytki [2]. Choroba dotyczy zwykle osób w średnim wieku, nieznacznie częściej chorują kobiety. W większości przypadków występują obrzęki w obrębie twarzy, ok. 1/3 pacjentów ma również objawy ze strony górnych dróg oddechowych i przewodu pokarmowego. Ta odmiana obrzęku, podobnie jak AAE-IH, nie ma charakteru rodzinnego [2, 20].

Diagnostyka: taka sama jak w AAE-IH.

Leczenie: dobre wyniki u dużej części chorych uzyskuje się, stosując kwas traneksamowy - syntetyczny aminokwas o działaniu przeciwkrwotocznym. U pacjentów z przeciwwskazaniami do jego przyjmowania można podjąć próbę stosowania GKS, cyklosporyny A lub omalizumabu. Odmienna odpowiedź poszczególnych pacjentów z AAE-InH na różne me- 
face, tongue, uvula and upper airways, but can also appear at any other location. Gastrointestinal symptoms are markedly less common than in hereditary angioedema with $\mathrm{C} 1$ inhibitor deficiency $[2,24]$.

Diagnostic workup: the fundamental step is detection of reduced serum C1-INH levels. In the majority of patients this parameter does not exceed $50 \%$ of normal value, although in some patients, in particular at an early stage of the disease, C1-INH abnormalities may manifest only during an edema attack. Reduction of serum C4 and C1q levels is also typical for this form of edema. If the clinical presentation and test results are inconclusive, identification of the SERPING1 mutation may be necessary to confirm this diagnosis [2].

Testing for co-morbidities, e.g. lymphoreticular proliferations, monoclonal gammopathy of uncertain significance (MGUS) or autoimmune diseases is necessary in all patients diagnosed with AAE-C1-INH. The recommended laboratory tests include: complete blood count with differential, C-reactive protein, proteinogram, serum protein electrophoresis, analysis of light chains in 24-hour urine collection. When complete blood count is abnormal, more detailed hematology tests should be performed [2, 10, 25].

Treatment: involves predominantly therapy of the potential underlying diseases. If such management is impossible or ineffective, and the edema is severe, anti-edema therapy should be initiated. Reduction of edema frequency and intensity can be achieved in some patients with C1-INH supplementation, but not all patients respond to this therapy, which is due to the extremely rapid catabolism of this inhibitor. Use of a type 2 bradykinin receptor antagonist (icatibant) or plasma kallikrein inhibitor (ecallantide) may also be attempted $[2,26]$. There are also reports documenting good therapeutic effects of rituximab, a monoclonal anti-CD20 antibody $[27,28]$. Attenuated androgens are less effective than in hereditary edema with C1-INH deficiency. Tranexamic acid is recommended for prophylaxis [2].

\section{Acquired angioedema related to ACE-I therapy (AAE-ACE-I)}

The pathomechanism of this disorder is due to ACE-I affecting bradykinin metabolism. Angiotensin-converting enzyme breaks down bradykinin to inactive metabolites. Inhibition of its activity by administration of ACE-I results in increased bradykinin levels and development of edema. This disease affects approximately $0.5 \%$ patients treated with ACE inhibitors. The development of edema is favored by coexistence of other factors that inhibit bradykinin catabolism $[2,29]$. Concomitant use of ACE-I and other drugs, e.g., immunosuppressants or calcium channel blockers, increases the risk of angioedema [30]. This tody terapii świadczy o heterogenności tej odmiany obrzęku oraz udziale różnych mediatorów w patomechanizmie choroby $[2,22,23]$.

\section{Nabyty obrzęk naczynioruchowy związany z niedoborem inhibitora $\mathrm{Cl}$ (AAE-CI-INH)}

Ta postać schorzenia rozpoznawana jest $\mathrm{u}$ chorych $\mathrm{z}$ niedoborem inhibitora $\mathrm{C} 1$ bez mutacji w genie $\mathrm{C} 1$ -INH (SERPING1) i bez rodzinnego wywiadu w kierunku obrzęku [2]. Obniżony poziom C1-INH w tej postaci AE może wynikać $z$ jego wzmożonego zużycia bądź wytwarzania przeciwciał neutralizujących C1-INH. Takie zjawisko występuje w przebiegu chorób limfoproliferacyjnych, gammapatii, jak również u osób ze schorzeniami autoimmunologicznymi, np. toczniem rumieniowatym układowym $[2,10,24]$.

AAE-C1-INH występuje u osób dorosłych obu płci, zwykle po 40. roku życia. Obrzęk najczęściej obejmuje twarz, język, języczek i górne drogi oddechowe, ale może pojawić się także w każdym innym umiejscowieniu. Objawy ze strony przewodu pokarmowego występują znacznie rzadziej niż we wrodzonym obrzęku naczynioruchowym z niedoboru $\mathrm{C} 1[2,24]$.

Diagnostyka: podstawowe znaczenie ma wykrycie obniżonego poziomu C1-INH w surowicy. U większości pacjentów poziom ten nie przekracza 50\% normy, chociaż u niektórych, szczególnie w początkowej fazie schorzenia, zaburzenia w zakresie C1-INH mogą być ewidentne tylko w czasie napadu obrzęku. Charakterystyczna dla tej postaci jest też redukcja surowiczego poziomu C4 i C1q. Jeżeli obraz kliniczny i wyniki badań są niejednoznaczne, do ostatecznego potwierdzenia niezbędne może być oznaczenie mutacji genu SERPING1 [2].

U wszystkich pacjentów z rozpoznaniem AAE-C1INH konieczne jest przeprowadzenie badań $w$ celu potwierdzenia lub wykluczenia schorzeń współistniejących, np. rozrostów limforetikularnych, gammapatii monoklonalnych (monoclonal gammapathy of uncertain significance - MGUS) lub chorób autoimmunologicznych. Zaleca się wykonanie takich badań laboratoryjnych, jak morfologia krwi z rozmazem, oznaczenie stężenia białka C-reaktywnego, proteinogram, elektroforeza białek surowicy, analiza łańcuchów lekkich w dobowej zbiórce moczu. W przypadku stwierdzenia nieprawidłowości w badaniach morfologicznych wskazane jest pogłębienie badań hematologicznych $[2,10,25]$.

Leczenie: polega przede wszystkim na terapii chorób, które mogą leżeć u podłoża obrzęku. Jeśli takie postępowanie nie jest możliwe bądź jest nieskuteczne, a obrzęki mają charakter gwałtowny, należy włączyć terapię przeciwobrzękową. U niektórych pacjentów można uzyskać zmniejszenie częstości występowania i nasilenia obrzęków poprzez zastosowanie suplementacji C1-INH, ale część chorych nie odpowiada na to 
type of edema usually affects patients over the age of 65 , more often women. The symptoms usually develop shortly after the initiation of ACE-I therapy, although cases of onset after many years of good treatment tolerance have also been reported. The symptoms usually affect the face, mainly lips and eyelids, the neck, the tongue and upper airways; they may be mild, but fatal cases of laryngeal edema have also been observed. Gastrointestinal symptoms are rarely reported [2].

Diagnostic workup: establishment of the relation between the edema symptoms and intake of ACE-I.

Treatment: discontinue the drug that causes the symptoms as soon as possible. Continuing the therapy may result in marked edema progression and the patient's death. There have been cases of persistence of the symptoms, usually in a milder form, despite discontinuation of ACE-I. This may occur in patients with a genetic defect of bradykinin metabolism or those in whom the drug revealed AAE-InH [31]. Off label use of icatibant, a drug approved for the treatment of hereditary angioedema with $\mathrm{C} 1$ inhibitor deficiency, may help in the therapy of persistent, recurrent edema [32]. Available data indicate that angiotensin receptor blockers (ARBs) are a safe alternative for patients with ACE-I hypersensitivity $[33,34]$.

\section{HEREDITARY ANGIOEDEMA (HAE)}

Hereditary angioedema is a genetic condition. In most patients with this disorder, the edema is caused by reduced concentration or inactivity of $\mathrm{C} 1$ complement component inhibitor (C1-INH). This defect results from a mutation in one of the two alleles of the SERPING1 gene which codes for C1-INH $[2,6]$. The inhibitor is a plasma protein composed of 478 amino acids, of a total molecular weight of $105 \mathrm{kD}$, produced by monocytes and megakaryocytes in the liver. C1INH prevents spontaneous activation of classical complement pathway by inhibiting serine protease. It also affects activation of kallikrein and plasmin in the fibrinolytic system, as well as activation of factor XI in the clotting system and activated factor XIIa. C1-INH deficiency or impaired function results in excessive synthesis of kinin-like $\mathrm{C} 2 \mathrm{~b}$ complement component and bradykinin. Bradykinin binds to bradykinin receptor B2, causing increased blood vessel permeability and edema.

With the progress of genetic testing, the pathomechanism of some other types of hereditary angioedema without C1-INH defect could be identified. So far there have been reports of edemas with a mutation of the gene coding for factor XII of the clotting system, with a mutation of the gene coding for plasminogen and with a mutation of the gene coding for angiopoi- leczenie, co jest związane z niezwykle szybkim katabolizmem tego inhibitora. Można też podjąć próbę zastosowania antagonisty receptora bradykininowego typu 2 (ikatybant) lub osoczowego inhibitora kalikreiny (ekalantyd) [2, 26]. Istnieją doniesienia na temat dobrego efektu terapeutycznego po zastosowaniu rytuksyma$\mathrm{bu}$ - monoklonalnego przeciwciała anty-CD20 [27, 28]. Atenuowane androgeny są mniej skuteczne niż we wrodzonej postaci obrzęku z niedoboru C1-INH. Jako profilaktykę obrzęków zaleca się stosowanie kwasu traneksamowego [2].

\section{Nabyty obrzęk naczynioruchowy związany z leczeniem inhibitorami konwertazy angiotensyny (AAE-ACE-I)}

Patomechanizm tego schorzenia wiąże sie z wpływem ACE-I na metabolizm bradykininy. Konwertaza angiotensyny bierze udział $\mathrm{w}$ rozpadzie bradykininy do nieaktywnych metabolitów. Zahamowanie aktywności konwertazy poprzez podanie jej inhibitorów powoduje wzrost stężenia bradykininy i rozwój obrzęku. Choroba dotyczy ok. 0,5\% pacjentów leczonych ACE-I. Wystąpieniu obrzęku sprzyja wspótistnienie innych czynników hamujących katabolizm bradykininy [2, 29]. Jednoczesne stosowanie z ACE-I innych leków, m.in. leków immunosupresyjnych lub blokerów kanałów wapniowych, zwiększa ryzyko pojawienia się obrzęków naczynioruchowych [30]. Ta odmiana obrzęku występuje zwykle u osób powyżej 65. roku życia, częściej u kobiet. Objawy najczęściej rozwijają się w krótkim czasie po rozpoczęciu terapii ACE-I, chociaż opisano także przypadki wystąpienia obrzęku po wielu latach dobrej tolerancji leku. Objawy dotyczą przede wszystkim twarzy, głównie warg i powiek, okolic szyi, jak również języka i górnych dróg oddechowych; mogą mieć charakter łagodny, ale opisano również przypadki śmiertelne związane z obrzękiem krtani. Rzadko opisywane są objawy ze strony przewodu pokarmowego [2].

Diagnostyka: ustalenie związku objawów obrzęku z przyjmowaniem ACE-I.

Leczenie: jak najszybsze odstawienie leku wywołującego objawy. Kontynuowanie terapii może prowadzić do znacznej progresji obrzęku i zgonu pacjenta. Opisywano przypadki utrzymywania się objawów, zwykle o łagodniejszym przebiegu, pomimo odstawienia ACE-I. Może to dotyczyć pacjentów z genetycznym defektem metabolizmu bradykininy lub tych, u których lek spowodował AAE-InH [31]. W terapii uporczywych, nawracających obrzęków pomocne może być stosowanie off label ikatybantu - leku zarejestrowanego do leczenia wrodzonego obrzęku wywołanego niedoborem inhibitora C1 [32]. Dostępne dane wskazują, że antagoniści receptora angiotensyny II (angiotensin receptor blockers - ARB) 
etin 1 . The cause of hereditary angioedema remains unknown in some patients $[6,10,11]$.

Types of HAE:

1) with C1-INH deficiency (HAE-C1-INH):

a) HAE-1 - due to C1-inhibitor deficiency,

b) HAE-2 - due to C1-inhibitor dysfunction;

2) with normal C1-INH (HAE-nC1-INH):

a) HAE-FXII - hereditary angioedema due to a mutation in the factor XII gene,

b) HAE-PLG - hereditary angioedema due to a mutation in the plasminogen gene,

c) HAE-ANG - hereditary angioedema due to a mutation in the angiopoietin 1 gene,

d) HAE-KNG1 - hereditary angioedema due to a mutation in the kininogen-1 gene,

e) HAE-UNK - hereditary angioedema of unknown origin.

Depending on the involvement of individual mediators in the pathomechanism, mast cell mediator-related (mainly histamine-related) and non-histaminergic forms of angioedema have been identified. The latter mainly include isolated edema (not associated with urticaria), in particular their hereditary forms - bradykinin is a predominant mediator here (table 2) $[2,6,15]$. Participation of individual mediators in various types of stanowią bezpieczną alternatywę dla ACE-I u pacjentów z nadwrażliwością na te leki $[33,34]$.

\section{WRODZONY OBRZĘK NACZYNIORUCHOWY (HAE)}

Obrzęk w postaci wrodzonej jest uwarunkowany genetycznie. U największej liczby chorych w tej grupie czynnikiem etiopatogenetycznym obrzęku jest zmniejszenie stężenia lub brak aktywności inhibitora składowej C1 układu dopełniacza (C1-INH). Defekt ten jest wynikiem mutacji w jednym $\mathrm{z}$ dwóch alleli genu SERPING1, kodującego C1-INH $[2,6]$. Inhibitor jest białkiem osoczowym zbudowanym z 478 aminokwasów o łącznej masie 105 kD, wytwarzanym w wątrobie oraz przez monocyty i megakariocyty. C1-INH zapobiega spontanicznej aktywacji klasycznej drogi dopełniacza poprzez hamowanie proteazy serynowej. Wpływa ponadto na aktywację kalikreiny i plazminy w układzie fibrynolitycznym, a także czynnika XI w układzie krzepnięcia i zaktywowanego czynnika XIIa. Niedobór lub upośledzenie funkcji C1-INH prowadzi do nadmiernej syntezy kininopodobnego fragmentu C2b dopełniacza oraz bradykininy. Bradykinina wiąże się z receptorem bradykininowym B2, co powoduje zwiększoną przepuszczalność naczyń krwionośnych i powstanie obrzęku.

Table 2. Involvement of mediators in individual types of angioedema

\begin{tabular}{|c|c|c|c|}
\hline \multirow[t]{4}{*}{ Induced by bradykinin } & \multirow[t]{2}{*}{ With CI-INH deficiency/defect } & Hereditary & HAE-I, HAE-2 \\
\hline & & Acquired & AAE-CI-INH \\
\hline & \multirow[t]{2}{*}{ With normal $\mathrm{Cl}-\mathrm{INH}$} & Hereditary & $\begin{array}{c}\text { HAE-nCI-INH } \\
\text { (HAE-FXII, } \\
\text { HAE-ANG, } \\
\text { HAE-PLG } \\
\text { HAE-KNGI } \\
\text { HAE-UNK) }\end{array}$ \\
\hline & & Acquired & AAE-ACE-I \\
\hline \multirow{2}{*}{$\begin{array}{l}\text { Induced by mast cell } \\
\text { mediators }\end{array}$} & Mediated by lgE & \multicolumn{2}{|c|}{ With anaphylaxis/urticaria } \\
\hline & Non-IgE-dependent & \multicolumn{2}{|c|}{ With urticaria } \\
\hline $\begin{array}{l}\text { Induced by unknown } \\
\text { mediators }\end{array}$ & & Idiopathic & \\
\hline
\end{tabular}

Tabela 2. Udział mediatorów w poszczególnych odmianach obrzęku naczynioruchowego

\begin{tabular}{|c|c|c|c|}
\hline \multirow[t]{4}{*}{ Indukowane bradykininą } & \multirow{2}{*}{$\begin{array}{c}\text { Z niedoborem lub defektem } \\
\mathrm{CI}-\mathrm{INH}\end{array}$} & Wrodzone & HAE-I, HAE-2 \\
\hline & & Nabyte & $\mathrm{AAE}-\mathrm{CI}-\mathrm{INH}$ \\
\hline & \multirow[t]{2}{*}{ Z prawidłowym CI-INH } & Wrodzone & $\begin{array}{c}\text { HAE-nCI-INH } \\
\text { (HAE-FXII, } \\
\text { HAE-ANG, } \\
\text { HAE-PLG } \\
\text { HAE-KNGI } \\
\text { HAE-UNK) }\end{array}$ \\
\hline & & Nabyte & AAE-ACE-I \\
\hline \multirow{2}{*}{$\begin{array}{l}\text { Indukowane mediatorami } \\
\text { mastocytów }\end{array}$} & Mediowane lgE & \multicolumn{2}{|c|}{ Z anafilaksją lub pokrzywką } \\
\hline & Niezależne od lgE & \multicolumn{2}{|c|}{ Z pokrzywką } \\
\hline $\begin{array}{l}\text { Wywołane nieznanymi } \\
\text { mediatorami }\end{array}$ & \multicolumn{3}{|c|}{ Idiopatyczne } \\
\hline
\end{tabular}


Table 3. Clinical and therapeutic differences between histaminergic and non-histaminergic angioedema

\begin{tabular}{lcc} 
Clinical features & \multicolumn{2}{c}{ Type of angioedema } \\
\cline { 2 - 3 } & Histaminergic & Non-histaminergic \\
\hline Onset & Sudden (minutes) & Slow (hours) \\
\hline Duration & $12-24$ hours & N8-72 hours or longer \\
\hline Coexisting urticaria & Common & Possible \\
\hline Laryngeal edema & Possible & Rare \\
\hline Bronchospasm & Common & Common \\
\hline Abdominal pain & Possible & Rare \\
\hline Drop of blood pressure & Common & No effect
\end{tabular}

Tabela 3. Kliniczne i terapeutyczne różnice pomiędzy obrzękiem zależnym i niezależnym od histaminy

\begin{tabular}{lcc} 
Cechy kliniczne & \multicolumn{2}{c}{ Typ obrzęku naczynioruchowego } \\
\cline { 2 - 3 } & Obrzęk zależny od histaminy & Obrzęk niezależny od histaminy \\
\hline Początek & Nagły (minuty) & Powolny (godziny) \\
\hline Czas trwania & $12-24$ godziny & $48-72$ godziny lub dłużej \\
\hline Wspótistnienie pokrzywki & Często & Nigdy \\
\hline Obrzęk krtani & Może wystąpić & Może wystąpić \\
\hline Skurcz oskrzeli & Często & Rzadko \\
\hline Bóle brzucha & Możliwe & Częste \\
\hline Spadek ciśnienia & Często & Rzadko \\
\hline Skuteczność LP, GKS, adrenaliny & Dobry efekt & Brak efektu
\end{tabular}

LP - leki przeciwhistaminowe, GKS - glikokortykosteroidy.

angioedema affects both the clinical presentation of the disease and response to therapy (table 3) [18, 19].

\section{Hereditary angioedema with $\mathrm{Cl}-\mathrm{INH}$ deficiency $(\mathrm{HAE}-\mathrm{Cl}-\mathrm{INH})$}

It presents in 2 forms:

a) HAE-1 - related to quantitative $\mathrm{C} 1$ esterase inhibitor deficiency; the most common form of HAE.

b) HAE-2 - a markedly less common form with reduced activity of $\mathrm{C} 1$ inhibitor despite its normal concentration.

This condition is caused by a mutation in one of the two alleles of the SERPING1 (serpin family G member) gene coding for C1-INH. It is an autosomal dominant condition, thus most patients have a positive family history. De novo mutations have been reported as the cause of the disease in approximately $20-25 \%$ of cases; in these cases family history is negative [1, $10,35]$. Despite the fact that the gene defect is present since birth, symptoms rarely manifest in the neonatal period or during infancy [36]. The onset usually occurs at a young age, most commonly between 5 and 11 years, but sometimes the first episode occurs in adulthood. This condition usually manifests as the edema of deeper skin layers and subcutaneous tissue of variable location (face, chest, limbs, genital areas). It may also affect mucosa of the throat, larynx and
Wraz z rozwojem badań genetycznych wyjaśniono patomechanizm niektórych innych postaci wrodzonego obrzęku naczynioruchowego, bez obecności defektu C1-INH. Do tej pory opisano postacie obrzęku z mutacją genu czynnika XII układu krzepnięcia, $\mathrm{z}$ mutacją genu plazminogenu, $\mathrm{z}$ mutacją genu angiopoetyny i z mutacją genu kininogenu 1 . U części chorych przyczyna obrzęku wrodzonego jest nieznana $[6,10,11]$.

Odmiany HAE:

1) z niedoborem C1-INH (HAE-C1-INH):

a) HAE-1 - ze zmniejszonym stężeniem C1-INH (hereditary angioedema due to C1-inhibitor deficiency),

b) HAE-2 - z zaburzeniem funkcji C1-INH (hereditary angioedema due to C1-inhibitor dysfunction);

2) z prawidłowym C1-INH (HAE-nC1-INH):

a) HAE-FXII - z mutacją genu czynnika XII (hereditary angioedema due to a mutation in factor XII).

b) HAE-PLG - z mutacją genu plazminogenu (hereditary angioedema due to a mutation plasminogen),

c) HAE-ANG - z mutacją genu angiopoetyny 1 (hereditary angioedema due to a mutation angiopoietin 1 ),

d) HAE-KNG1 - z mutacją genu kininogenu 1 (hereditary angioedema due to a mutation kininogen-1),

e) HAE-UNK - o nieznanej przyczynie (hereditary angioedema of unknown origin). 
gastrointestinal tract. The severity of lesions is highly variable, from poorly symptomatic or asymptomatic to very severe cases with numerous life-threatening attacks $[2,6,10]$.

Edema attacks are most commonly triggered by factors such as medical procedures, mechanical injuries, physical exertion, infections or stress. In females, the symptoms are sometimes exacerbated during puberty and pregnancy, which is due to increased estrogen levels. Moreover, some drugs, such as oral contraceptives, hormone replacement agents or ACE-I may increase the frequency and severity of the attacks $[6,37]$.

Diagnostic workup: an important factor is history of recurrent angioedema episodes without urticaria wheals that do not respond to drugs conventionally used to relieve edema, such as antihistamines, GCS or adrenaline. Patients with this form of the disease often also report laryngeal edema and recurrent abdominal pain, often persisting for a few days. A history of ACE-I use should be ruled out and attention should be paid to other drugs and allergens that can trigger the symptoms. Checking for similar symptoms in a family member is very important since it confirms HAE with high degree of probability. Laboratory tests in this type of edema are focused on measuring complement components - primarily the concentration and activity of $\mathrm{C} 1$ inhibitor and C4 component. Most commonly C1-INH activity does not exceed $30 \%$ of normal value. These tests should be performed twice with a 1-3 month interval, using different blood samples. If normal values of these parameters are obtained in a patient with a clinical suspicion of HAE-C1-INH, the test should be repeated during an edema attack. In most patients, C4 component levels are reduced in the asymptomatic period as well, both in HAE-1 and in HAE-2 [2, 6, 10, 38].

Apart from family history, age at first onset and co-morbidities, differential diagnostic workup of hereditary angioedema with C1-INH deficiency (HAE$\mathrm{C} 1-\mathrm{INH}$ ) and acquired angioedema (AAE-C1-INH) should include the levels of $\mathrm{C} 1 \mathrm{q}$ component. This parameter is reduced in approximately $75 \%$ of AAE-C1INH patients, whereas it is usually normal in HAEC1-INH $[2,6,38,39]$. Genetic testing (for SERPING1 mutations) is usually required in diagnostically challenging cases, e.g. with negative family history and late onset of symptoms, and where it is necessary to differentiate from hereditary angioedema with normal level and activity of C1-INH $[6,10]$.

Treatment of patients differs depending on the disease phase. In the management of HAE-C1-INH patients, it is important to identify and eliminate factors that trigger and exacerbate symptoms, such as ACE-I or estrogen products [2].

In an acute edema attack, a complement component $\mathrm{C} 1$ inhibitor (C1-INH) should be used. This group in-
W zależności od udziału poszczególnych mediatorów w patomechanizmie obrzęku wyróżnia się jego formy związane $\mathrm{z}$ mediatorami komórek tucznych (głównie z histaminą) oraz niezależne od histaminy. Do tej drugiej grupy należą przede wszystkim obrzęki izolowane (niezwiązane z pokrzywką), a szczególnie ich postacie wrodzone, w których mediatorem jest głównie bradykinina (tab. 2) [2, 6, 15]. Udział poszczególnych mediatorów w różnych odmianach obrzęku naczynioruchowego wpływa zarówno na obraz kliniczny choroby, jak i reakcję na leczenie (tab. 3) [18, 19].

\section{Wrodzony obrzęk naczynioruchowy z niedoboru $\mathrm{CI}-\mathrm{INH}$ (HAE-CI-INH)}

Występuje w 2 postaciach:

a) HAE-1 - postać związana z ilościowym niedoborem inhibitora C1 esterazy, najczęstsza odmiana HAE,

b) HAE-2 - postać z obniżoną aktywnością inhibitora C1 przy jego prawidłowym stężeniu, znacznie rzadsza.

U podłoża schorzenia leży mutacja w jednym z dwóch alleli genu SERPING1 (serpin family G member) kodującego C1-INH. Jest to cecha dziedziczona autosomalnie dominująco, dlatego u większość chorych ma dodatni wywiad rodzinny. W ok. 20-25\% przypadków opisano mutacje de novo odpowiedzialne za powstanie choroby; w takich sytuacjach wywiad rodzinny jest ujemny [1, 10, 35]. Defekt genu jest obecny już po urodzeniu, jednak objawy bardzo rzadko pojawiają się w wieku noworodkowym lub niemowlęcym [36]. Chorobę stwierdza się zwykle wcześnie, najczęściej pomiędzy 5. a 11. rokiem życia, ale niekiedy pierwszy incydent obrzęku występuje u osób dorosłych. Objawy mają postać obrzęków głębokich warstw skóry i tkanki podskórnej o różnym umiejscowieniu (twarz, klatka piersiowa, kończyny, okolice narządów płciowych). Obrzęk może dotyczyć również błon śluzowych gardła, krtani oraz przewodu pokarmowego. Nasilenie zmian jest bardzo zróżnicowane u poszczególnych osób - od postaci skąpoobjawowych lub bezobjawowych do bardzo ciężkiego przebiegu z licznymi atakami obrzęku, które stanowią zagrożenie dla życia pacjenta $[2,6,10]$.

Napady obrzęku najczęściej są wyzwalane przez takie czynniki, jak zabiegi medyczne, uraz mechaniczny, wysiłek fizyczny, infekcje lub stres. U kobiet nasilenie objawów obserwuje się niekiedy w okresie dojrzewania i ciąży, co wiąże się ze wzrostem stężenia estrogenów. Ponadto niektóre leki, m.in. doustne środki antykoncepcyjne, preparaty stosowane w hormonalnej terapii zastępczej czy ACE-I, mogą zwiększać częstość i intensywność ataków [6,37].

Diagnostyka: istotne są dane $\mathrm{z}$ wywiadu wskazujące na występowanie nawracających incydentów obrzęku naczynioruchowego bez obecności bąbli pokrzywkowych, które nie reagują na leki klasycz- 
cludes plasma-derived products: pdC1-INH (Berinert) and recombinant rhC1-INH (Ruconest). These drugs are administered intravenously, at a per kg body weight dose. Berinert is used at a dose of $20 \mathrm{U} / \mathrm{kg}$ body weight, and Ruconest at a dose of $50 \mathrm{U} / \mathrm{kg}$ body weight. If the symptoms are severe, sometimes the dose needs to be repeated $[2,10,40]$.

An alternative for the substitution therapy is type 2 bradykinin receptor antagonist (Firazyr). The drug is administered subcutaneously at a fixed dose of $30 \mathrm{mg}$ as a ready solution in a pre-filled syringe. Occasionally a patient requires another drug dose - it should be administered 6 hours after the first injection.

In Poland, therapy with plasma-derived recombinant C1-INH products and bradykinin receptor antagonists is only reimbursed in acute, life-threatening HAE-C1-INH attacks that affect the throat, larynx or the abdominal cavity. In children, only Berinert is fully reimbursed. Ruconest is reimbursed up to the age of 13, and Firazyr is not reimbursed for pediatric patients. All drugs currently used in Poland to stop an attack are approved for self-administration at home.

Patients and/or their caretakers should undergo regular training in the correct and safe use of the drug to be able to initiate the therapy on their own as soon as the first symptoms appear. Early injection of the drug reduces the severity and shortens the duration of symptoms. All patients diagnosed with HAE should be equipped with drugs for self-use, in amounts sufficient to treat 2 attacks; they should always have them at hand.

If the above-mentioned products are not available, fresh frozen plasma can be used to treat an acute attack. Another drug effective in the treatment of acute attacks, a kallikrein blocker (ecallantide), is not available in Poland [10, 40, 41].

Chronic treatment to prevent acute edema attacks in HAE-C1-INH patients involves long-term, continuous administration of drugs to reduce the number and severity of attacks. A decision to initiate such therapy is based mainly on the frequency, severity and location of the edema, the effectiveness of rescue treatment in stopping the edema and the socio-occupational situation of the patient.

The first choice in prophylactic treatment is plasma-derived C1-INH, to be administered subcutaneously every 3-4 days, or lanadelumab to be given subcutaneously every 2 weeks [2, 40, 42, 43]. Landelumab is a monoclonal antibody, a specific kallikrein inhibitor in the kallikrein-kinin system. Studies revealed its high and lasting efficacy in the inhibition of plasma kallikrein activity, which was associated with a significant reduction of the HAE attack frequency [40, 41]. nie stosowane w stanach obrzękowych, takie jak leki przeciwhistaminowe, GKS czy adrenalina. Pacjenci z tą postacią choroby często zgłaszają także obrzęki krtani oraz nawracające, najczęściej kilkudniowe bóle brzucha. W wywiadzie należy wykluczyć stosowanie przez chorego ACE-I, a także zwrócić uwagę na inne leki i alergeny, które mogą być przyczyną objawów. Bardzo istotne jest ustalenie, czy podobne objawy występowały u któregoś z członków rodziny, co z dużym prawdopodobieństwem pozwala na potwierdzenie HAE. Badania laboratoryjne $w$ tej postaci obrzęku opierają się przede wszystkim na pomiarze składowych układu dopełniacza - głównie stężenia i aktywności inhibitora $\mathrm{C} 1$ oraz składowej $\mathrm{C} 4$. Aktywność C1-INH najczęściej nie przekracza 30\% normy. Powyższe oznaczenia powinno się wykonywać dwukrotnie w odstępach 1-3 miesięcy z różnych próbek krwi. Uzyskanie prawidłowych wartości tych parametrów u chorego z klinicznym podejrzeniem HAE-C1-INH wymaga powtórzenia badań w czasie napadu obrzęku. Poziom składowej C4 u większości chorych jest obniżony również $\mathrm{w}$ okresie bezobjawowym, zarówno w HAE-1, jak i w HAE-2 [2, 6, 10, 38].

W różnicowaniu postaci wrodzonej HAE-C1-INH z postacią nabytą AAE-C1-INH oprócz wywiadu rodzinnego i wieku wystąpienia pierwszych objawów oraz wykluczenia chorób współistniejących istotne znaczenie ma poziom składowej C1q. Parametr ten jest obniżony u ok. 75\% chorych z AAE-C1-INH, natomiast w HAE-C1-INH jest najczęściej prawidłowy $[2,6,38,39]$. Wykonanie badań genetycznych (mutacje genu SERPING1) jest zwykle konieczne w przypadkach trudnych diagnostycznie, np. z ujemnym wywiadem rodzinnym i późnym początkiem objawów, a także $\mathrm{w}$ celu różnicowania $\mathrm{z}$ wrodzonymi obrzękami z prawidłowym poziomem i aktywnością C1-INH $[6,10]$.

Leczenie różni się $\mathrm{w}$ zależności od fazy choroby. U pacjentów z HAE-C1-INH istotne jest wykrycie i wyeliminowanie czynników wywołujących i zaostrzających objawy, takich jak przyjmowanie ACE-I czy preparatów zawierających estrogeny [2].

W ostrym ataku obrzęku należy zastosować inhibitor składowej C1 dopełniacza (C1-INH). W tej grupie wyróżnia się preparaty osoczopochodne - pdC1-INH (Berinert) oraz rekombinowane - rhC1-INH (Ruconest). Leki te podaje się dożylnie $\mathrm{w}$ dawce przeliczanej na kilogram masy ciała: Berinert - 20 j./ kg m.c., Ruconest $-50 \mathrm{j} . / \mathrm{kg}$ m.c. Przy nasilonych objawach pacjent wymaga czasem powtórzenia dawki leku $[2,10,40]$.

Alternatywą dla leczenia substytucyjnego jest stosowanie antagonisty receptora bradykininowego typu 2 (Firazyr). Lek jest podawany podskórnie $\mathrm{w}$ stałej dawce $30 \mathrm{mg} \mathrm{w}$ postaci gotowego roztworu w ampułkostrzykawce. Niekiedy pacjent wymaga podania kolejnej dawki - należy ją zaaplikować 6 godzin po pierwszej iniekcji. 
Androgen derivatives (danazol, stanazolol) are an alternative for this long-term therapy. These products are effective in prevention of acute edema attacks in most HAE-C1-INH patients, but their use is limited by numerous adverse effects. Moreover, these drugs cannot be used in children and pregnant or lactating women. The dose is selected individually for each patient. Long-term use of danazol at doses exceeding $200 \mathrm{mg}$ daily is not recommended $[2,44]$.

Antifibrinolytic drugs (tranexamic acid) are given when other drugs are contraindicated or unavailable. These products can also be used in children. Tranexamic acid is administered orally, usually at a dose of 30-50 mg/ $\mathrm{kg}$ body weight, in 2-3 divided doses. It is usually well tolerated. The drug should be avoided in patient with high risk of thrombosis $[2,6,40]$.

Short-term therapy to prevent the attacks should be administered in HAE-C1-INH patients before medical procedures involving mechanical compression or injuries in the oral cavity, throat and larynx, as well as procedures involving disruption of tissue integrity that can induce an attack. Plasma-derived C1-INH is the therapy of choice in these situations. This product should be used at a therapeutic dose at least 6 hours before the procedure. If the inhibitor is unavailable, fresh frozen plasma should be used $[2,45]$.

\section{Hereditary angioedema with normal $\mathrm{CI}-\mathrm{INH}$ (HAE-nCI-INH)}

This variation of isolated angioedema is diagnosed in patients with a positive family history with normal C1 inhibitor levels and activity. Four types with genetic abnormalities have been identified, and one of unknown etiology:

1) HAE-FXII - with a mutation in factor XII of the clotting system,

2) HAE-PLG - with a mutation in the plasminogen gene,

3) HAE-ANG - with a mutation in the angiopoietin 1 gene,

4) HAE-KNG1 - with a mutation in the kininogen-1 gene, and

5) HAE-UNK - angioedema of unknown origin, where no inducing mutation could be identified [2, $6,10,46,47]$.

Clinical presentation, diagnostic workup and therapy of this type of edema are identical as in HAE$\mathrm{C} 1-\mathrm{INH}$. The definite differential diagnosis requires genetic testing. If autoantibodies to C1-INH are present, plasmapheresis and use of cytotoxic drugs, androgens and tranexamic acid may be required.

Table 4 presents typical results of laboratory tests performed as part of the diagnostic workup of each type of isolated angioedema $[2,6,48]$.
W Polsce leczenie osoczopochodnymi i rekombinowanymi preparatami C1-INH oraz antagonistą receptora bradykininowego jest refundowane tylko w ostrych, zagrażających życiu atakach HAE-C1-INH, obejmujących gardło, krtań lub jamę brzuszną. U dzieci pełna refundacja dotyczy tylko preparatu Berinert. Ruconest jest refundowany od 13. roku życia, a Firazyr nie jest objęty refundacją dla pacjentów pediatrycznych. Wszystkie aktualnie stosowane w Polsce leki do przerywania napadu są dopuszczone do samodzielnego przyjmowania przez pacjenta w warunkach domowych.

Chorzy i/lub ich opiekunowie powinni być regularnie szkoleni w zakresie prawidłowego i bezpiecznego stosowania leku, aby w razie pierwszych objawów obrzęku mogli samodzielnie rozpocząć terapię. Wczesne wstrzyknięcie leku ogranicza nasilenie objawów i skraca czas trwania napadu. Wszystkich chorych z rozpoznanym HAE należy zaopatrzyć w leki do samodzielnego zastosowania, w ilości wystarczającej do leczenia 2 napadów, które powinni mieć zawsze przy sobie.

W przypadku braku wymienionych wyżej preparatów można zastosować w ostrym ataku obrzęku świeżo mrożone osocze. Inny lek skuteczny w leczeniu ostrych napadów obrzęku, bloker kalikreiny (ekalantyd) jest w Polsce niedostępny [10, 40, 41].

Leczenie przewlekłe zapobiegające ostrym atakom obrzeku u chorych z HAE-C1-INH polega na długotrwałym, stałym podawaniu leków w celu zmniejszenia liczby i ciężkości ataków. Decyzja o włączeniu tego typu terapii zależy przede wszystkim od częstości występowania, nasilenia i umiejscowienia obrzęków, skuteczności leczenia doraźnego przerywającego obrzęki oraz od sytuacji społeczno-zawodowej chorego.

W profilaktyce lekiem pierwszego wyboru jest osoczopochodny C1-INH podawany podskórnie co 3-4 dni lub lanadelumab podawany podskórnie co 2 tygodnie [2, 40, 42 43]. Landelumab jest przeciwciałem monoklonalnym, swoistym inhibitorem kalikreiny w układzie kalikreina-kinina. $W$ badaniach stwierdzono dużą i trwałą skuteczność tego leku w hamowaniu aktywności kalikreiny osoczowej, co wiązało się z istotną redukcją częstości występowania napadów HAE [40, 41].

Alternatywą dla tej terapii długoterminowej jest stosowanie pochodnych androgenowych (danazol, stanazolol). Są one skuteczne w zapobieganiu ostrym napadom obrzęku u większości chorych z HAE-C1-INH, lecz ich stosowanie ograniczają liczne działania niepożądane. Ponadto leki te nie mogą być podawane dzieciom oraz kobietom w ciąży i w czasie laktacji. Dawkę dobiera się indywidualnie u każdego chorego. Nie zaleca się długotrwałego stosowania dawki przekraczającej $200 \mathrm{mg}$ danazolu dziennie $[2,44]$.

Leki antyfibrynolityczne (kwas traneksamowy) podaje się w przypadku przeciwwskazań lub braku dostępności innych leków. Preparaty te mogą być również stosowane u dzieci. Kwas traneksamowy stosuje się doustnie, 
R.J. Nowicki, E. Grubska-Suchanek, G. Porębski, M.L. Kowalski, K. Jahnz-Różyk, T. Matuszewski, L. Rudnicka, M. Kulus, W. Barańska-Rybak, R. Czajkowski, Z. Doniec, C. Kowalewski, B. Kręcisz, M. Lange, J. Narbutt, M. Olszewska, M. Sokołowska-Wojdyło, A. Szczerkowska-Dobosz, R. Śpiewak, M Trzeciak, A Wilkowska

Table 4. Results of laboratory tests as part of diagnostic workup of angioedema

\begin{tabular}{lccccc}
\hline Type of AE & CI-INH levels & $\mathrm{CI}$-INH activity & C4 levels & Clq levels & Other tests \\
\hline HAE-I & Reduced & Reduced & Reduced & Normal & Mutation in SERPINGI gene \\
\hline HAE-2 & Normal/increased & Reduced & Reduced & Normal & Mutation in SERPINGI gene \\
\hline HAE-FXII, HAE-ANG, & Normal & Normal & Normal & Normal & Relevant gene mutation \\
HAE-PLG, HAE-KNGI & & & & & \\
\hline HAE-UNK & Normal & Normal & Normal & Normal & No detectable genetic abnormalities \\
\hline AAE-CI-INH & Normal/reduced & Reduced & Reduced & Reduced & Anti-Cl-INH antibodiespresent/absent \\
\hline AAE-IH, AAE-InH, & Normal & Normal & Normal & Normal & No detectable genetic abnormalities \\
AAE-ACE-I & & & & \\
\hline
\end{tabular}

Tabela 4. Wyniki badań laboratoryjnych $w$ diagnostyce obrzęku naczynioruchowego

\begin{tabular}{|c|c|c|c|c|c|}
\hline Typ AE & $\begin{array}{l}\text { Stężenie } \\
\text { CI-INH }\end{array}$ & $\begin{array}{c}\text { Aktywność } \\
\text { Cl-INH }\end{array}$ & Stężenie C4 & Stężenie $\mathrm{Clq}$ & Inne badania \\
\hline HAE-I & Obniżenie & Obniżenie & Obniżenie & Norma & Mutacja genu SERPINGI \\
\hline HAE-2 & $\begin{array}{c}\text { Norma lub } \\
\text { podwyższenie }\end{array}$ & Obniżenie & Obniżenie & Norma & Mutacja genu SERPINGI \\
\hline $\begin{array}{l}\text { HAE-FXII, HAE-ANG, } \\
\text { HAE-PLG, HAE-KNG I }\end{array}$ & Norma & Norma & Norma & Norma & Mutacja odpowiedniego genu \\
\hline HAE-UNK & Norma & Norma & Norma & Norma & Brak uchwytnych zaburzeń genetycznych \\
\hline AAE-CI-INH & $\begin{array}{l}\text { Norma lub } \\
\text { obniżenie }\end{array}$ & Obniżenie & Obniżenie & Obniżenie & $\begin{array}{l}\text { Przeciwciała przeciw } \mathrm{Cl}-\mathrm{INH} \text { obecne } \\
\text { lub nieobecne }\end{array}$ \\
\hline $\begin{array}{l}\text { AAE-IH, AAE-InH, } \\
\text { AAE-ACE-I }\end{array}$ & Norma & Norma & Norma & Norma & Brak uchwytnych zaburzeń genetycznych \\
\hline
\end{tabular}

\section{MONITORING OF HAE PATIENTS}

Disease activity and quality of life of patients should be assessed at regular follow-up visits at specialized HAE therapy centers. Patients with unstable disease require more frequent follow-up visits. $\mathrm{C} 4$ levels and C1-INH levels or activity monitoring is used to monitor the therapeutic effect in HAE-1/2 and AAE-C1-INH patients.

Patients with another edema episode involving the oral cavity and/or larynx should be hospitalized at departments able to perform expedited intubation and mechanical ventilation.

Children of parents diagnosed with HAE should be immediately tested for this disease [40].

\section{CONFLICT OF INTEREST}

The authors declare no conflict of interest. najczęściej w dawce 30-50 mg/kg m.c. w 2-3 dawkach podzielonych. Tolerancja leku jest zazwyczaj dobra. Należy unikać stosowania tego preparatu u chorych z podwyższonym ryzykiem wystąpienia zakrzepicy $[2,6,40]$.

Leczenie krótkoterminowe zapobiegające napadom należy stosować u chorych z HAE-C1-INH przed zabiegami medycznymi związanymi z mechanicznym uciskiem i urazami w jamie ustnej, gardle i krtani oraz przed zabiegami związanymi z przerwaniem ciągłości tkanek, które mogą indukować napad. Lekiem z wyboru w tych sytuacjach jest osoczopochodny C1-INH. Preparat powinien być zastosowany w dawce terapeutycznej co najmniej 6 godzin przed zabiegiem. W przypadku braku dostępności inhibitora należy zastosować świeżo mrożone osocze [2, 45].

\section{Wrodzony obrzęk naczynioruchowy z prawidłowym CI-INH (HAE-nCI-INH)}

Ta odmiana izolowanego obrzęku naczynioruchowego dotyczy pacjentów z dodatnim wywiadem rodzinnym, u których stężenie i aktywność inhibitora C1 jest prawidłowa. Wyróżnia się 4 typy obrzęku z zaburzeniami genetycznymi i jeden o nieznanym podłożu: 1) HAE-FXII - z mutacją genu czynnika XII układu krzepnięcia,

2) HAE-PLG - z mutacją genu plazminogenu,

3) HAE-ANG - z mutacją genu angiopoetyny 1 , 
4) HAE-KNG1 - z mutacją genu kininogenu 1 oraz

5) HAE-UNK - obrzęk naczynioruchowy o nieznanym podłożu, w którym nie udaje się wykryć mutacji sprawczej $[2,6,10,46$, 47].

Obraz kliniczny, diagnostyka i terapia tej postaci obrzęku są identyczne jak w HAE-C1-INH. Ostateczne różnicowanie wymaga wykonania badań genetycznych. W przypadku obecności autoprzeciwciał przeciwko C1-INH konieczne są wykonywanie plazmaferezy oraz stosowanie leków cytotoksycznych, androgenów i kwasu traneksamowego.

Typowe wyniki badań laboratoryjnych w diagnostyce poszczególnych odmian izolowanego obrzęku naczynioruchowego przedstawiono $\mathrm{w}$ tabeli 4 [2, 6, 48].

\section{MONITOROWANIE PACJENTÓW Z HAE}

Ocenę aktywności choroby i jakości życia chorych powinno się przeprowadzać podczas regularnych wizyt kontrolnych w ośrodkach specjalizujących się w leczeniu HAE. Pacjenci z niestabilnym przebiegiem choroby wymagają częstszych kontroli. Pomiar stężenia C4 oraz stężenia lub aktywności C1-INH służy do monitorowania efektu terapii u pacjentów z HAE-1/2 i AAE-C1-INH.

Chorzy z kolejnym epizodem obrzęku w obrębie jamy ustnej i/lub krtani powinni być hospitalizowani na oddziałach z możliwością wykonania pilnej intubacji i zastosowania mechanicznej wentylacji.

Dzieci rodziców, u których rozpoznano HAE, należy niezwłocznie zbadać pod kątem tej choroby [40].

\section{KONFLIKT INTERESÓW}

Autorzy nie zgłaszają konfliktu interesów.

\section{References}

\section{Piśmiennictwo}

1. Zuberbier T., Asero R., Bindslev-Jensen C., Walter Canonica G., Church M.K., Gimenez-Arnau A.M., et al: EAACI/GA(2)/ LEN/EDF/WAO guideline: definition, classification and diagnosis of urticaria. Allergy 2009, 64, 1417-1426.

2. Cicardi M., Aberer W., Banerji A., Bas M., Berstein J.A., Bork K., et al.: Classification, diagnosis, and approach to treatment for angioedema: consensus report from Hereditary Angioedema International Working Group. Allergy 2014, 69, 602-616.

3. Kaplan A.P.: Angioedema. World Allergy Organ J 2008, 1, 103-113.

4. Quincke H.: Uber akute sumschriebenedhautoderm. Monatshe Prakt Dermatol 1982, 1, 129-131.

5. Zingale L.C., Beltrami L., Zanichelli A., Maggioni L., Pappalardo E., Cicardi B., et al.: Angioedema without urticaria: a large clinical survey. CMAJ 2006, 175, 1065-1070.

6. Maurer M., Magerl M., Ansotegui I., Aygoren-Pursun E., Betschel S., Bork K., et al.: The international WAO/EAACI guideline for the management of hereditary angioedema - The 2017 revision and update. Allergy 2018, 73, 1575-1596.

7. Craig T., Ayören-Púrsún E., Bork K., Bowen T., Boysen H., Farkas H., et al.: WAO Guideline for the management of hereditary angioedema. World Allergy Organ J 2012, 5, 182-199.

8. Bork K., Brehler R., Witzke G., Boor S., Heineke W., Hardt J.: Blindness, tetraspasticy and other signs of irreversible brain damage in hereditary angioedema. Ann Allergy Asthma Immunol 2017, 118, 520-521.

9. Bork K., Hardt J., Witzke G.: Fatal laryngeal attacks and mortality in hereditary angioedema due to C1-INH deficiency. J Allergy Clin Immunol 2012, 130, 692-697.

10. Porębski G., Gocki J., Juchacz A., Kucharczy A., Matuszewski T., Olejniczak K., et al.: Postepowanie we wrodzonym obrzeku naczynioruchowym z niedoboru C1 - stanowisko sekcji HAE Polskiego Towarzystwa Alergologicznego. Część I: klasyfikacja, patofizjologia, objawy kliniczne i rozpoznanie. Alergol Pol 2018, 5, 98-108. 
11. Łukowska-Smorawska K., Samochocki Z.: Wrodzony obrzęk naczynioruchowy. Alergoprofil 2014, 10, 45-50.

12. Betschel S., Badiou J., Binkley K., Borici-Mazi R., Hebert J., Kanani A., et al.: The International/Canadian Hereditary Angioedema guideline. Allergy Asthma Clin Immunol 2019, 15, 72.

13. Busse P.J., Christansen S.C.: Hereditary angioedema. N Engl J Med 2020, 382, 1136-1148.

14. Belbezier A., Bocquet A., Bouillet L.: Idiopathic angioedema: current challenges. J Asth Allergy 2020, $13,137-144$.

15. Kaplan A.P., Greaves M.W.: Angioedema. J Am Acad Dermatol 2005, 53, 373-388.

16. Bork K., Wulff K., Rossmann H., Steinmuller-Magin L., Braenne I., Witzke G., et al.: Hereditary angioedema cosegregating with a novel kininogen 1 gene mutation changing the N-terminal cleavage site of bradykinin. Allergy 2019, 74, $2479-2481$.

17. Veronez C.L., Grumach A.S.: Angioedema without urticaria: novel findings which must be measured in clinical setting. Curr Opin Allergy Clin Immunol 2020, 20, 253-260.

18. Depetri F., Tedeschi A., Cugno M.: Angioedema and emergency medicine: from pathophysiology to diagnosis and treatment. Eur J Int Med 2019, 59, 8-13.

19. Cugno M., Nussberger J., Cicardi M., Agostoni A.: Bradykinin and the pathophysiology of angioedema. Int Immunopharmacol 2003, 3, 311-317.

20. Bygum A., Vestergaard H.: Acquired angioedema - occurrence, clinical features and associated disorders in a Danish nationwide patient cohort. Int Arch Allergy Immunol 2013, 162, 149-155.

21. Bucher M.C., Petkovic T., Helbling A., Steiner U.C.: Idiopathic non-histaminergic acquired angioedema: a case series and discussion of published clinical trials. Clin Trans Allergy 2017, 7, 27.

22. Wu M.A., Perego F., Zanichelli A., Cicardi M.: Angioedema phenotypes: disease expression and classification. Clin Rev Allergy Immunol 2016, 51, 162-169.

23. Faisant C., Du Thanh A., Mansard C., Deroux A., Boccon-Gibod I., Bouillet L.: Idiopathic non histaminergic angioedema: successful treatment with omalizumab in five patients. J Clin Immunol 2017, 37, 80-84.

24. Zingale I.C., Castelli R., Zanichelli A., Cicardi M.: Acquired deficiency of the inhibitor of the first complement component: presentation, diagnosis, course and conventional management. Immunol Allergy Clin North Am 2006, 26, 669-690.

25. Casteli R., Deliliers D.L., Zingale L.C.: Limphoproliferative disease and acquired C1 inhibitor deficiency. Haematologica 2007, 92, 716-718.

26. Patel N.S., Fung S.M., Zanichelli A.: Ecallantide for treatment of acute attacks of acquired C1 esterase inhibitor deficiency. Allergy Asthma Proc 2013, 34, 72-77.

27. Branellec A., Bouillet I., Javaud N., Mekinian A., Boccon-Gibod I., Blanchard-Delaunay C., et al.: Acquired C1-inhibitor deficiency: 7 patients treated with rituximab. J Clin Immunol 2012, 32, 936-941.

28. Hassan A., Amarger S., Tridon A., Ponard D., Souteyrand P., D'Incan M.: Acquired angioedema responding to rituximab. Acta Derm Venereol 2011, 91, 733-734.

29. Brown N.J., Snowden M., Griffin M.R.: Reccurent angiotensin-converting enzyme inhibitor-associated angioedema. JAMA $1997,278,232-233$

30. Montinaro V., Cicardi M.: ACE inhibitor-mediated angioedema. Int Immunopharmacol 2020; 78: 106081. doi: 10.1016/j.intimp.2019.106081.

31. Beltrami L., Zanichelli A., Zingale L., Vacchini R., Carugo S., Cicardi M.: Long-term follow-up of 111 patients with angiotensyn-converting enzyme inhibitor-related angioedema. J Hypertens 2011, 29, 2273-2277.

32. Bas M., Greve J., Stelter K., Bier H., Stark T., Hoffmann T.K., et al.: Therapeutic efficacy of icatibant in angioedema induced by angiotensin-converting enzyme inhibitors: a case series. Ann Emerg Med 2010, 56, 278-282.

33. Toh S., Reichman M.E., Houstoun M., Southworth M.R., Ding X., Hernandez A.F., et al.: Comparative risk for angioedema associated with the use of drugs that target the renin-angiotensin-aldosterone system. Arch Intern Med 2012, 172, 1582-1589.

34. Rasmussen E.R., Pottegård A., Bygum A., von Buchwald C., Homoe P., Hallas J.: Angiotensin II receptor blockers are safe in patients with prior angioedema related to angiotensin-converting enzyme inhibitors - a nationwide registry-based cohort study. J Intern Med 2019, 285, 553-561.

35. Kaplan A.P., Joseph K.: Complement, kinins and hereditary angioedema: mechanisms of plasma instability when C1 inhibitor is absent. Clin Rev Allergy Immunol 2016, 57, 207-215.

36. Czarnobilska E., Bulanda M.: Wrodzony obrzęk naczynioruchowy u dzieci. Alergia Astma Immunol 2018, 23, 193-198.

37. Longhurst H.J., Bork K.: Hereditary angioedema: an update on causes, manifestations and treatment. Br J Hosp Med July 2019, 80, 391-398.

38. Giavina-Bianci P., Arruda L.K., Aun M.V., Campos R.A., Chong-Neto H.J., Constantino-Silva R.N., et al.: Brazylian guidelines for hereditary angioedema management - 2017 updade part 1: definition, classification and diagnosis. Clinics 2018, 73, e310.

39. Cicardi M., Suffritti C., Perego F., Caccia S.: Novelties in the diagnosis and treatment of angioedema. Invest Allergol Clin Immunol 2016, 26, 212-221.

40. Porębski G., Gocki J., Juchacz A., Kucharczyk A., Matuszewski T., Olejniczak K., et al.: Postępowanie we wrodzonym obrzęku naczynioruchowym z niedoboru C1 - stanowisko sekcji HAE Polskiego Towarzystwa Alergologicznego. Część II: leczenie i zapobieganie napadom, monitorowanie choroby i postępowanie w sytuacjach szczególnych. Alergol Pol 2018, 5, 109-120.

41. Bork K., Bernstein J.A., Maching T., Craig T.J.: Efficacy of different medical therapies for the treatment of acute laryngeal attacks of hereditary angioedema due to C1-esterase inhibitor deficiency. J Emerg Med 2016, 50, 567-580.

42. Busse P.J., Farkas H., Banerji A., Lumry W.R., Longhurt H.J., Sexton D.J., et al.: Lanadelumab for the prophylactic treatment of hereditary angioedema with C1 inhibitor deficiency: a review of preclinical and phase I studies. BioDrugs 2019, 33, 33-43.

43. Bova M., Valerieva A., Wu M.A., Senter R., Perego F.: Lanadelumab injection treatment for the prevention of hereditary angioedema (HAE): design, development and place in therapy. Drug Des Devel Ther 2019, 13, 3635-3646.

44. Porębski G., Obtułowicz K.: Atenuowane androgeny w leczeniu wrodzonego obrzęku naczynioruchowego. Alergol Immunol 2015, 12, 21-25. 
45. Farkas H., Zotter Z., Csuka D., Szabo E., Nebenfuhrer G., Temesszentandrasi G., et al.: Short-term prophylaxis in hereditary angioedema due to deficiency of the C1-inhibitor: a long-term survey. Allergy 2012, 67, 1586-1593.

46. Bafunno V., Firinu D., D'Apolito M.: Mutation of thee angiopoietin-1 gen (ANGPT1) associated with a new type of hereditary angioedema. J Allergy Clin Immunol 2018, 141, 1009-1017.

47. Bork Z., Zibat A., Ferrari D.M., Wollnik B., Schon M.P., Wulff K., et al.: Hereditary angioedema in a single family with specific mutations in both plasminogen and SERPING1 genes. J Dtsch Dermatol Ges 2020, 18, 215-223.

48. Nowicki R.J.: Choroby alergiczne: obrzęk naczynioruchowy. In: Interna Szczeklika 2019. P. Gajewski (ed.). Medycyna Praktyczna, Kraków, 2019, 2214-2220.

Received: 13.07 .2020

Accepted: 22.07 .2020

Otrzymano: $13.07 .2020 \mathrm{r}$

Zaakceptowano: $22.07 .2020 \mathrm{r}$.

How to cite this article

Nowicki R.J., Grubska-Suchanek E., Porębski G., Kowalski M.L., Jahnz-Różyk K., Matuszewski T., Rudnicka L., Kulus M., Barańska-Rybak W., Czajkowski R., Doniec Z., Kowalewski C., Kręcisz B., Lange M., Narbutt J., Olszewska M., Sokołowska-Wojdyło M., Szczerkowska-Dobosz A., Śpiewak R., Trzeciak M., Wilkowska A.: Angioedema. Interdisciplinary diagnostic and therapeutic recommendations of the Polish Dermatological Society (PTD) and Polish Society of Allergology (PTA). Dermatol Rev/Przegl Dermatol 2020, 107, 293-307. DOI: https:// doi.org/10.5114/dr.2020.99875. 